Research Article

\title{
The Effect of Portfolio Assessment on Iranian EFL Learners' Autonomy and Writing Skills
}

\author{
Abbas Biglari $\mathbb{D}^{1},{ }^{1}$ Siros Izadpanah $\mathbb{D}^{1},{ }^{1}$ and Ehsan Namaziandost $\mathbb{D}^{2}$ \\ ${ }^{1}$ Department of English Language Teaching, Zanjan Branch, Islamic Azad University, Zanjan, Iran \\ ${ }^{2}$ Department of English, Shahrekord Branch, Islamic Azad University, Shahrekord, Iran
}

Correspondence should be addressed to Siros Izadpanah; cyrosizadpanah@yahoo.com

Received 14 July 2021; Accepted 30 October 2021; Published 11 November 2021

Academic Editor: Yu-Min Wang

Copyright (C) 2021 Abbas Biglari et al. This is an open access article distributed under the Creative Commons Attribution License, which permits unrestricted use, distribution, and reproduction in any medium, provided the original work is properly cited.

The portfolio assessment is a purposeful and systematic collection of students' work that is intended to show progress over time. The researchers employed the Oxford quick placement test, autonomy questionnaire, and topic-based paragraph writings as the pretest and posttest. The design of the study was quasiexperimental. To this end, researchers chose 120 learners with the convenience sampling method, which were 60 learners at the upper-intermediate and 60 learners at the advanced level. Participants were divided into two homogeneous groups (30 learners) such that there were two groups at the upper-intermediate level and two groups at an advanced level as experimental and control groups. A piloted writing pretest was given to both groups before the treatment. The experimental group had received the treatment of four writing tasks to perform. In order to address the research questions, descriptive statistics and covariant analysis were used. Based on the results achieved from the first research question, portfolio assessment has a positive significant effect on Iranian EFL learners' autonomy on both upper-intermediate and advanced levels. The results also indicated that portfolio assessment has a positive significant effect on Iranian EFL learners' writing skills on both upper-intermediate and advanced levels.

\section{Introduction}

A study into the history of language teaching and pedagogy suggests that there has been a close interrelationship between language teaching and assessment. Writing skill is the most neglected area in language learning $[1,2]$. It seems to have more agreement that speaking and listening are the skills most needed when trying to succeed in a foreign language environment [3]. Writing is an ongoing process that needs much practice and attention [4]. Many EFL learners such as Iranian EFL students have problems in developing their writing ability in general and their descriptive writing ability in particular [5, 6]. For many years, portfolio assessment has been been one of the most relevant methods for EFLT because of its massive efficiency in the learning process. One of the process-based evaluation techniques is certainly portfolios [7]. The constructivist approach is presented on the basis of portfolio studies because the student needs construction in his/her mind for each study and activity to be placed in the portfolio [8]. He/she reflects his/her learning to his/her studies. From this perspective, it can be said that portfolio application contributes to constructivist learning theory [9]. In the process of compiling a portfolio, a constructive form emerges in the student's mind that he or she can summarize without the teacher's help what he or she has learned, what he or she has not mastered, and what he or she has learned during the certain period. In this way, students can learn self-evaluation correctly [10].

The complexity of factors involved in effective writing would presume that a substantial amount of time is dedicated to writing in language programs. Nonetheless, according to Aini, Mufid, and Sari [11, 12]; Nunan [13]; and White and Arndt [14], it has tended to be a muchneglected part of the language program, despite the power of writing as a permanent record, as a form of expression, and as a means of communication. 
Learner autonomy has been a crucial concept in the field of language learning for the last three decades. This has been the result of development due to the development of classroom-based approaches in education $[15,16]$.

In order to enhance learners' writing skill and autonomy, as the two communicative and pedagogical elements in language learning, various approaches are presented to provide the learners with an environment in which they can practice and learn the language and experience different contexts [8,17-20]. The idea underlying learner autonomy is based on the philosophy that if the students are encouraged toward decision making, goal setting, and reflecting in their process of learning, they, eventually, become more enthusiastic and purposeful about their learning and, consequently, learning can be more enjoyable, focused, and fruitful to them $[21,22]$.

The aim of this research was to investigate the effect of portfolio assessment on Iranian EFL learners' autonomy and writing skills in upper-intermediate and advanced levels.

\subsection{Review of the Literature}

1.1.1. The Concept of Portfolio. Portfolio assessment has been used as an alternative approach to standardized testing for more than two decades. It commonly refers to a print or web-based dossier, where students regularly revisit and evaluate their learning trajectories by way of multimodal artifacts [7]. Portfolio assessment in education aims to equip learners with self-reflective capacity so that they are able to monitor, review, and improve their academic performances independent of the teacher's instructed guidance [9, 23-26].

Moreover, Virgin and Bharati [27] believe that a portfolio should express the students' efforts and attainment and teachers' thought of portfolio assessment as an educational tool, teachers' and students' role in portfolio development, and teachers' belief of portfolio strengths and weaknesses are crucial.

The portfolio assessment becomes an attractive alternative way of increasing students' writing skills. A portfolio plays an important role in improving students' writing skills. It is an effective instructional technique as well as an assessment tool that can provide evidence of knowledge and skills [28]. Furthermore, portfolio assessment can offer authentic information about the progress of students and can be used as a means of assisting students to overcome their writing anxiety in foreign or second-language learning [29-33].

1.2. Writing Skill. The common view that writing skill in a foreign language is difficult to acquire may lead to loss of motivation and, therefore, lack of success among English as a Foreign Language (EFL) learners [34]. Portfolio application as an alternative method in foreign language teaching may alleviate such a problem and appear as an effective means to increase students' motivation and success levels in EFL writing classes. Its application, therefore, needs to be disseminated for teaching English in the EFL learners $[35,36]$.
In writing, the writer needs to express the idea in the mind to the paper or any other kinds of writing tool which is readable. Writing is a complex activity involving many skills to determine the ideas and transfer the ideas onto a piece of paper clearly and comprehensibly for the reader [36-39].

The application of portfolio assessment in academic writing has been proved as an impetus to writing practice. Results show the feasibility of the portfolio assessment and indicate the improvement in confidence, involvement, selfassessment awareness, and overall learner identity formation. The findings have pedagogical implications that portfolio-based classroom is successful as the driving force of learning and in addressing the private college students' learning difficulties vis-a-vis EAP writing task $[10,35,40,41]$.

1.3. Autonomy. For the first time, the phrase was contrived in 1981 by Henri Holec, titled the father of learner autonomy. Since then, many depictions and explanations have been created for the term. Contingent upon the author, background, and debate level that tutors have reached was imagined as an individual human feature or a political pattern or an educational maneuver. Autonomy is seen as a goal or instrument or sometimes both in education $[15,21]$.

In the last twenty years, the concept of learner autonomy has become influential as a goal in many parts of the world [42-44]. Several arguments may be used in favor of developing autonomy in language learners that autonomous learning is more effective than other approaches to learning and that the learner needs to take charge of his own learning especially outside the classroom [45]. The notion of autonomy in learning has been part of educational philosophy and has recently been identified in educational policy as crucial to the development of lifelong learning in the learning society [46]. Some researchers believe that the ultimate aim of education is for the individual to develop the autonomy of thought to create new, original ideas rather than just recycle old ones. Little [47] also claims that all genuinely successful learning is in the end autonomous.

Using portfolio assessment, students were motivated to be self-assessors of their own development in writing. They also focus not only on their previous ability or performance but also set goals to improve their writing competence. It means that the students became more aware of the importance of self-reflection and autonomy learning through self-evaluation activities during completing their portfolio assessment [7]. Furthermore, the students understand well what criteria were used to evaluate their work, and they will also understand what the lecturer expected from them so that their writing competence can improve. Therefore, by using portfolio assessment, it was proved that engaging students directly in the assessment process will help students to learn writing autonomously [48].

\section{Method}

2.1. Participants. Researchers used convenience (availability sampling) in the study. The participants of this study were Iranian EFL learners studying at the Ayandegra Institute, Zanjan, Iran. They were selected among male learners, 
approximately aged from 21 to 33 years. The participants were chosen among the learners who had been placed in the upper-intermediate and advanced levels based on the Oxford quick placement test that the researchers used in order to place the learners in the upper-intermediate and advanced levels. For this study 120 learners had been selected, 60 learners at the upper-intermediate levels divided into two groups as treatment and control groups and 60 learners in the advanced levels divided into two groups as treatment and control groups. In order to ensure that the participants of both experimental groups had the same characteristics in terms of writing and autonomy, all participants were asked to fill an autonomy questionnaire and participate in a writing test prior to the treatment.

2.2. Instruments. In order to investigate the effect of portfolio assessment on learners' autonomy and writing, the researchers employed the following instruments: the Oxford quick placement test, autonomy questionnaire, topic-based paragraph writings as the pretest and posttest, and writing rubric score.

Oxford quick placement test: to elicit the information about the learners' proficiency in the English language and to get the homogeneous group, the Oxford quick placement test (2007) was used.

Autonomy questionnaire: an autonomy questionnaire designed by Spratt, Humphreys, and Chan (2002, pp. 265-266) was used as a pretest and posttest in the present study. The questionnaire consisted of four sections with a total of 52 items and was based on a Likert scale. The questionnaire was validated by professors at Islamic Azad University, and the validated version was used in a study by Fahim and Behdani [49].

The students were given 20 minutes to respond to the autonomy questionnaire. The scoring of the first section ranged from 1 (not at all) to 5 (completely), the second section ranged from 1 (very poor) to 5 (very good), the third section ranged from 5 to 1 , respectively, to the $1,2,3,4$, and 5 choices, and then, the last section's scores ranged from 1 (never) to 4 (often). Consequently, the results could vary from 52-233. The higher the mark the students obtained, the more autonomous they were.

Topic-based paragraph writings as the pretest and posttest: five TOEFL argumentative (agree or disagree) writing topics were taken from the Internet. One of the topics was chosen by the researchers to be used as the pretest and posttest. Four other topics were chosen to be given to the learners during the course to write about.

Writing rubric score: the writings of the participants were evaluated based on the criteria developed by Wang and Liao [50] which can be applied to any type of writing. This rubric has six sections including purpose statement, sense of audience, organization and development, support for ideas, understanding of topic, and use of grammar. The total marks could be from 0 to 24 at most for each person.

2.3. Procedure and Data Collection. In order to collect appropriate data for this study, the following steps were taken: first of all, learners had participated in the Oxford quick placement test. After dividing learners into upper- intermediate and advanced groups, they were asked to fill the autonomy questionnaire. By the result of the autonomy questionnaire, learners were divided into two homogeneous groups. In the first session, they were asked to write a paragraph of at least 150 words in 30 minutes on the subject of "Do you agree or disagree with the following statement? "When people succeed, it is entirely because of hard work. Luck has nothing to do with their success. Use specific reasons and examples to explain your position."

The topic was given to them as the pretest. During paragraph writing, they were allowed to use a dictionary or to ask the teacher questions if they did not know a word. Two raters, the researcher and his master, scored the paragraphs based on the writing rubric score.

During the treatment, the learners were assigned four topics to write a paragraph of at least 150 words for each subject. Each group went through different treatments which will be explained below. After the treatment, learners were given the same topic that was used as the pretest which functioned as the posttest.

\subsection{Research Questions.}

(1) Question 1: does portfolio assessment have a positive effect on Iranian learners' autonomy?

(2) Question 2: does portfolio assessment have a positive effect on Iranian learners' writing skill?

\subsection{Null Hypotheses}

Hypothesis 1. Portfolio assessment has a positive effect on Iranian learners' autonomy.

Hypothesis 2. Portfolio assessment has a positive effect on Iranian learners' writing skill.

2.6. Research Design. The design of the study was quasiexperimental, with control and experimental groups having a pretest and posttest. The independent variable was the implementation of portfolio assessment, and the dependent variables were descriptive writing and autonomy. The descriptive writing was measured through a pretest and a posttest. The experimental and control groups also received the same learning content. About autonomy, again, the researchers had given the same questionnaire to experimental and control groups at the end of the last session.

2.7. Experimental Group: Portfolios. In the next session after the pretest, the teacher explained to the learners how they were going to collect the four writings in a folder during the course. The "Portfolio Assessment for the Teaching and Learning of Writing" by Ricky Lam [24] was used as a guide book, and the teacher tried to teach chapters 3 to 5 during the sessions.

It was mentioned that the topics were related to the learners' book; thus, after teaching the ordinary material of the book, the teacher gave the chosen topic to the learners and they were asked to write about it in the classroom. They 
were asked to write the paragraph in 30 minutes and to manage their time.

To increase student's autonomy, they participated in the classroom. They were divided into four groups, and in each session, one group had to present a given part of the book to other learners and teachers at the beginning of the classroom. Moreover, learners were free to participate actively during the class and the teacher asked them some questions.

At the end of the class, all essays were collected and scored by the teacher and given back to the learners' next session. They were also given a folder to write their names on it and to keep their writings and checklists there and deliver them to the teacher in the last session. The treatment in this group went on like this for the whole semester until the learners had written on all four topics.

2.8. Control Group: The Traditional Approach. In the control group, the teacher assigned the learners a topic to write about it in the class. The teacher scored the writings and gave the papers back to the learners. This is the method usually used in institutes, schools, and universities in Iran as observed by the researchers.

The control group did not have the book, and after some lessons that the teacher gave them for writing about topic sentences, supporting sentences, coherence, and unity, they received conventional writing instruction. Then, the teacher gave the same topic to the experimental group to write at least 150 words about it in the classroom in 30 minutes. Afterwards, the teacher collected essays, scored them at home, and gave the scored papers back to the learners in the next session. It should be mentioned that the teacher did not give any feedback to the learners except the score. The learners in this group wrote on all four topics and received scores for their writings during the semester.

2.9. Data Analysis. Following the objectives of the study, the data collection was carefully performed and the raw data were entered into SPSS (version 22) to run the required statistical analyses and respond to the research questions of this study.

In this research, descriptive and inferential statistical methods were used to analyze the collected data and test the hypotheses. In descriptive methods, an attempt was made to describe the research data by presenting tables and using descriptive statistical tools such as central indicators and dispersion, in order to contribute to the clarity of the subject. Researchers also used inferential statistical methods to test hypotheses.

In the inferential analysis section, researchers first test the hypothesis of normality using the Kolmogorov-Smirnov test. Afterwards, the analysis of covariance and $T$-test were used to test findings. Covariance analysis is a comprehensive type of analysis of variance in which, while comparing the means of one or more groups and estimating one or more independent variables, the effect of one or more intervening, covariate, or covariate variables is excluded from the equation. In other words, covariance analysis is a statistical method that allows the effect of one independent variable on the dependent variable to be examined while eliminating the effect of another variable.

\section{Results}

We conducted a test of the first research question in the upper-intermediate groups, "Does portfolio assessment have a positive effect on Iranian upper-intermediate learners' autonomy?"

Descriptive indices of autonomy variable scores in control and upper-intermediate groups in the pretest and posttest are given.

As can be seen in Table 1, the average of an autonomy variable in the upper-intermediate control group in the pretest is 130.86 and in the posttest is 132.50. Also, the average autonomy variable in the experimental upper-intermediate group in the pretest is 130.83 and the posttest is 166.86. It should be noted that the increase in the mean of the autonomy variable in the posttest stage was higher than that in the pretest in the experimental group compared to the control group.

To test this hypothesis, an independent- and pairedsample $t$-test were used. To perform these tests, it is necessary to use the Kolmogorov-Smirnov test for checking the normality distribution of the whole data in both pretest and posttest of autonomy and writing tests. Therefore, researchers first examined the assumption of using both the pretest and posttest.

The results of the abovementioned test are given in Table 2.

According to the significant values that are shown in Table 2, which are higher than 0.05 , the null hypothesis of normality of the discussed variables is accepted at a significant level of 0.05 .

Due to the normality of the samples of the study, an independent- and paired-sample $t$-test were used to test the first hypothesis. The results of the independent-sample test for the test of comparing the mean of an autonomy variable in the pretest stage between the control group and the experimental group and also in the posttest stage between the control group and the experimental group are given in Tables 3 and 4.

As can be seen, in the pretest stage, the average of the autonomy variable in the control group was 130.86 and in the experimental group was 130.83 . The results of the independent samples test at 5\% error level showed ( $\mathrm{Sig}=0.997)$ that there is no significant difference between the mean of autonomy variable in the control group and the experimental group in the pretest stage. Also, in the posttest stage, the average autonomy variable in the control group was 132.50 and in the experimental group was 166.86 , and the results of the independent samples test showed an error level of $5 \%(\mathrm{sig}=0.000)$. There is a significant difference between the mean of the autonomy variable in the control group and the experimental group in the posttest stage.

The results of paired-sample test for the test comparing the mean of autonomy variable in the control group in two stages of the pretest and posttest and also comparing the 
TABLE 1: Descriptive statistics in upper-intermediate groups.

\begin{tabular}{llccccc}
\hline \multirow{2}{*}{ Intermediate group } & & $\mathrm{N}$ & Min & Max & Mean & $\begin{array}{c}\text { Std. } \\
\text { deviation }\end{array}$ \\
\hline \multirow{2}{*}{ Control } & Auton-pre & 30 & 70.00 & 195.00 & 130.86 & 32.53 \\
& Auton-pos & 30 & 75.00 & 195.00 & 132.50 & 32.43 \\
\hline \multirow{2}{*}{ Experiment } & Auton-pre & 30 & 75.00 & 183.00 & 130.83 & 30.23 \\
& Auton-pos & 30 & 108.00 & 213.00 & 166.86 & 30.20 \\
\hline
\end{tabular}

TABLE 2: Test table for normality of variables in the pretest the upper-intermediate groups for autonomy.

\begin{tabular}{lcccc}
\hline Step & Variables & Sig & Decision & Test result \\
\hline \multirow{2}{*}{ Pretest } & Control & 0.074 & $P>0.05$ & Normal \\
& Experiment & 0.2 & $P>0.05$ & Normal \\
\hline \multirow{2}{*}{ Posttest } & Control & 0.2 & $P>0.05$ & Normal \\
& Experiment & 0.08 & $P>0.05$ & Normal \\
\hline
\end{tabular}

mean of autonomy variable in the experimental group in two stages of the pretest and posttest are given in Table 5.

As can be seen from Table 5, there is no significant difference between the means of the autonomy variable in the pretest and posttest stages in the control group ( $\operatorname{sig}=0.159$ ), but in the control group, there is a significant difference between the mean of autonomy variable in the pretest and posttest $(\mathrm{Sig}=0.00)$. Therefore, it can be concluded that, in the experimental group, the mean of the autonomy variable in the posttest significantly increased relatively to the pretest.

We conducted a test of the first research question in the advanced group, "Does portfolio assessment have a positive effect on Iranian upper-intermediate learners' autonomy?"

Descriptive indices of autonomy variable scores in the pretest and posttest in advanced-level control and experimental groups that are recorded in Table 6.

As can be seen in Table 6, the average of the autonomy variable in the advanced control group in the pretest is 165.56 and the posttest is 166.16. Also, the average autonomy variable in the advanced experimental group in the pretest is 165.50 and in the posttest is 201.76. It should be noted that the increase in the mean of the autonomy variable in the posttest was more than that in the pretest in the advanced experimental group compared to the control group. To test this hypothesis, independent- and paired-sample $t$-test were used. To use these tests, it is necessary to use the Kolmogorov-Smirnov test for checking the normality distribution of the whole data in both the pretest and posttest of autonomy and writing tests. Therefore, researchers first examined the assumption of using both the pretest and posttest.

3.1. Scores Normality. In this study, the Kolmogorov-Smirnov test was used to investigate the hypothesis of normality of independent variable scores.

The results of the abovementioned test are given in Table 7.

Given the values of sig in Table 7, all of which are higher than 0.05, the null hypothesis means that the variables in question are normal at the significance level of 0.05 .
The results of the independent-sample test for the test of comparing the mean of an autonomy variable in the pretest stage between the control group and the experimental group and also in the posttest stage between the control group and the experimental group are given in Tables 8 and 9 .

As can be seen in the pretest stage, the average of the autonomy variable in the control group was 165.56 and in the experimental group was 165.50 . Also, the results of the independent-sample test at $5 \%$ error level showed $(\operatorname{sig}=0.989)$ that there is no significant difference between the mean of the autonomy variable in the control group and the experimental groups in the pretest stage. Furthermore, in the posttest stage, the mean of the autonomy variable was 166.16 in the control group and 201.76 in the experimental group. Besides, the results of the independent-sample test at 5\% error level showed $(\operatorname{sig}=0.00)$ that there is a significant difference between the mean of autonomy variable in the control group and the experimental group in the posttest stage.

The results of the paired-sample test for the test comparing the mean of the autonomy variable in the control group in two stages of pretest and posttest and besides comparing the mean of the autonomy variable in the experimental group in two stages of pretest and posttest are given in Table 10.

As can be seen from Table 10, in the control group, there is no significant difference between the mean of the autonomy variable in the pretest and posttest $(\mathrm{Sig}=0.452)$, but in the control group, there is a significant difference between the mean of autonomy in the pretest and posttest (sig=0.000). Therefore, it can be concluded that, in the experimental group, the mean of the autonomy variable in the posttest significantly increased comparatively to the pretest.

We conducted a test of the second research question, "Does portfolio assessment have a positive effect on Iranian learners' writing skill?”

3.2. Choosing Topics to Use in Writing Portfolio Effect. To select topics to use in the writing section, researchers focused on TOEFL writing subjects because the TOEFL test is a highquality standard to evaluate and teach students and it is preferred and accepted by universities worldwide. 
Table 3: Group statistics.

\begin{tabular}{lccccc}
\hline & Group & $\mathrm{N}$ & Mean & Std. deviation & Std. error mean \\
\hline \multirow{2}{*}{ Autonomy pretest } & Control & 30 & 130.86 & 32.53 & 5.93 \\
& Experiment & 30 & 130.83 & 30.23 & 5.51 \\
\hline \multirow{2}{*}{ Autonomy posttest } & Control & 30 & 132.50 & 32.43 & 5.92 \\
& Experiment & 30 & 166.86 & 30.20 & 5.51 \\
\hline
\end{tabular}

TABLE 4: Independent-sample test : a T-test for equality of means.

\begin{tabular}{lcccc}
\hline & $\mathrm{t}$ & $\mathrm{df}$ & Sig. (2-tailed) & Mean difference \\
\hline Autonomy pretest & .004 & 58 & .997 & .03333 \\
Autonomy posttest & -4.247 & 58 & .000 & -34.36667 \\
\hline
\end{tabular}

TABle 5: Paired-sample test: paired differences.

\begin{tabular}{lllccrrr}
\hline \multicolumn{1}{c}{ Mean } & \multicolumn{1}{c}{ Std. deviation } & & & \\
\hline Control & Pair 1 & Autonomy pretest and autonomy posttest & -1.63 & 6.18 & -1.45 & 29 \\
Experiment & Pair 1 & Autonomy pretest and autonomy posttest & -36.03 & 15.64 & -12.61 & 29 & .000 \\
\hline
\end{tabular}

TABLE 6: Descriptive statistic for autonomy in advanced groups.

\begin{tabular}{llccccc}
\hline Advanced group & & $\mathrm{N}$ & Min & Max & Mean & Std. deviation \\
\hline \multirow{2}{*}{ Control } & Autonomy pretest & 30 & 125.00 & 203.00 & 165.56 & 19.15 \\
& Autonomy posttest & 30 & 130.00 & 205.00 & 166.16 & 17.76 \\
\hline \multirow{2}{*}{ Experiment } & Autonomy pretest & 30 & 130.00 & 203.00 & 165.50 & 19.74 \\
& Autonomy posttest & 30 & 179.00 & 228.00 & 201.76 & 14.62 \\
\hline
\end{tabular}

TABLE 7: Test the normality of variables in the pretest and posttest (the advanced group for autonomy).

\begin{tabular}{lcccc}
\hline Step & Variables & Sig & Decision & \\
\multirow{2}{*}{ Pretest } & Control & 0.20 & $p>0.05$ & Test result \\
& Experiment & 0.2 & $p>0.05$ & Normal \\
\multirow{2}{*}{ Posttest } & Control & 0.08 & $p>0.05$ & Normal \\
& Experiment & 0.12 & $p>0.05$ & Normal \\
\hline
\end{tabular}

TABLE 8: Group statistics.

\begin{tabular}{lccccc}
\hline & Group & $\mathrm{N}$ & Mean & Std. deviation & Std. error mean \\
\hline \multirow{2}{*}{ Autonomy pretest } & Control & 30 & 165.56 & 19.15 & 3.49 \\
& Experiment & 30 & 165.50 & 19.74 & 3.60 \\
\hline \multirow{2}{*}{ Autonomy posttest } & Control & 30 & 166.16 & 17.76 & 3.24 \\
& Experiment & 30 & 201.76 & 14.62 & 2.66 \\
\hline
\end{tabular}

Additionally, researchers used the Lawshe CVR Content Validity Formula and interrater reliability between the two raters to check TOEFL question subjects' validity again in this research.

\subsection{Topic-Based Paragraph Writings as the Pretest and} Posttest. Among sixty TOEFL argumentative (agree or disagree) writing topics and by using Lawshe CVR (content validity ratio) and CVI (content validity index) $(0.42,0.79)$, five TOEFL argumentative (agree or disagree) writing topics were chosen.
By using Lawshe CVR and CVI, five TOEFL argumentative (agree or disagree) writing topics were selected among sixty subjects. The first topic was chosen by researchers to be used as the pretest and posttest. Four other topics were chosen to be given to the learners during the course to write about.

3.4. Interrater Reliability between the Two Raters. Interrater reliability is the extent to which two or more raters (or observers, coders, and examiners) agree. It addresses the issue of the consistency of the implementation of a rating system. Interrater reliability can be evaluated by using a number of 
TABLE 9: Independent-sample test: a T-test for equality of means.

\begin{tabular}{lcccc}
\hline & $\mathrm{t}$ & $\mathrm{df}$ & Sig. (2-tailed) & Mean difference \\
\hline Autonomy pretest & .013 & 58 & .989 & 0.066 \\
Autonomy posttest & -8.47 & 58 & .000 & -35.60 \\
\hline
\end{tabular}

TABLe 10: Paired-sample test: paired differences.

\begin{tabular}{|c|c|c|c|c|c|c|c|}
\hline & & & Mean & & Std. devi & & \\
\hline Control & Pair 1 & Autonomy pretest and autonomy posttest & -0.60 & 4.31197 & -0.76 & 29 & .452 \\
\hline Experiment & Pair 1 & Autonomy pretest and autonomy posttest & -36.26 & 15.60 & -12.72 & 29 & .000 \\
\hline
\end{tabular}

TABLE 11: Interrater reliability between the two raters in the upper-intermediate group (pretest and posttest).

\begin{tabular}{llcccccr}
\hline \multirow{2}{*}{ Group control } & $\mathrm{N}$ & Min & Max & Mean & Std. deviation & Pearson correlation & Sig \\
\hline \multirow{2}{*}{ Pre } & Writing skill- rater 1 & 30 & 10.00 & 21.00 & 14.20 & 2.65 & \multirow{2}{*}{0.96} \\
& Writing skill- rater 2 & 30 & 10.00 & 20.00 & 14.36 & 2.53 & 2.00 \\
\multirow{2}{*}{ Post } & Writing skill- rater 1 & 30 & 11.00 & 20.00 & 14.53 & 2.37 & \multirow{2}{*}{0.95} \\
& Writing skill- rater 2 & 30 & 10.00 & 21.00 & 14.56 & 2.52 & \multirow{2}{*}{0.00} \\
\hline
\end{tabular}

different statistics. High interrater reliability values refer to a high degree of agreement between two examiners. Low interrater reliability values refer to a low degree of agreement between the two examiners, Lange [51].

3.5. Interrater Reliability between the Two Raters in UpperIntermediate Groups. Before testing the second hypothesis about the effect of portfolio assessment on Iranian EFL learners' writing skills, descriptive indicators related to the scores given by the two referees in upper-intermediate control and experiment groups for the pretest and posttest and the correlation coefficient between the scores of these two referees were calculated.

As can be seen in Table 11, in both upper-intermediate control and experimental groups, pretest and posttest, the Pearson correlation coefficient between the scores of the two referees is significant at an error level of $5 \%$.

3.6. Interrater Reliability between the Two Raters in Advanced Groups. Before testing the second hypothesis about the effect of portfolio assessment on Iranian EFL learners' writing skills, descriptive indicators related to the scores given by the two referees in advanced control and experimental groups for pretest and posttest and the correlation coefficient between the scores of these two referees were calculated and are shown in Table 12.

We conducted a test of the second research question in the upper-intermediate groups, "Does portfolio assessment have a positive effect on Iranian learners' writing skill?

Descriptive indices of variable scores of writing skill in control, upper-intermediate, and advanced groups in the pretest and posttest are listed in Table 13.

As can be seen in Table 13, the mean writing skill score in the control group in the pretest is 14.28 and in the posttest is 14.55. Besides, the mean writing skill score in the experimental group in the pretest is 14.61 and the posttest is 18.78 . It is obvious that an increase in the mean writing skill score in the posttest stage is higher than that in the pretest in the experimental group.

To test this hypothesis, independent- and paired-sample $t$-tests were used. To use these tests, it is necessary to conduct the Kolmogorov-Smirnov test for checking the normality distribution of the whole data in both the pretest and posttest of autonomy and writing tests. Therefore, researchers first examined the assumption of using both the pretest and posttest.

3.7. Score Normality. In this study, the Kolmogorov-Smirnov test was used to test the hypothesis of normality of the variables of writing skill. The results of the abovementioned test are given in Table 14 .

The values of sig are given in Table 14, all of which are higher than 0.05 . The results of the independent-sample test for the test of comparing the average of the writing skill variable in the pretest stage between the control group and the experimental group and also in the posttest stage between the control group and the experimental group are given in Tables 15 and 16.

As can be seen in the pretest stage, the average of the writing skill variable in the control group is 14.28 and in the experimental group was equal to 14.61 . The results of independent-sample test at $5 \%$ error level showed $(\mathrm{sig}=0.59)$ that there is no significant difference between the mean of the writing skill variable in the control and the experimental groups in the pretest stage. In the posttest stage, the average of the writing skill variable in the control group was 14.55 and in the experimental group was 18.78. The results of independent-sample test at 5\% error level showed $(\operatorname{sig}=0.00)$ that there is a significant difference between the mean of the writing skill variable in the control and the experimental groups in the posttest stage. The results of the paired-sample test for comparing the average of the writing skill variable in the control group in the two stages of pretest and posttest and also comparing the average of the writing 
TABLE 12: Interrater reliability between the two raters in advanced groups (pretest and posttest).

\begin{tabular}{llllllcr}
\hline \multirow{2}{*}{ Group control } & $\mathrm{N}$ & Min & Max & Mean & Std. deviation & Pearson correlation & Sig \\
\hline \multirow{2}{*}{ Pre } & Writing skill- rater 1 & 30 & 10.00 & 21.00 & 14.20 & 2.65 & \multirow{2}{*}{0.96} \\
& Writing skill- rater 2 & 30 & 10.00 & 20.00 & 14.36 & 2.53 & 2.00 \\
\multirow{2}{*}{ Post } & Writing skill- rater 1 & 30 & 11.00 & 20.00 & 14.53 & 2.37 & \multirow{2}{*}{0.95} \\
& Writing skill- rater 2 & 30 & 10.00 & 21.00 & 14.56 & 2.52 & \multirow{2}{*}{0.00} \\
\hline
\end{tabular}

TABLE 13: Descriptive statistics for writing skill in upper-intermediate groups.

\begin{tabular}{lcccccc}
\hline & & N & Min & Max & Mean & Std. deviation \\
\hline \multirow{2}{*}{ Control } & Pretest & 30 & 10.00 & 20.50 & 14.28 & 2.57 \\
& Posttest & 30 & 10.50 & 20.50 & 14.55 & 2.42 \\
\hline \multirow{2}{*}{ Experiment } & Pretest & 30 & 10.00 & 18.00 & 14.61 & 18.78 \\
& Posttest & 30 & 15.00 & 22.00 & 1.86 \\
\hline
\end{tabular}

TABLE 14: Test table for normality of variables in the pretest and posttest (the upper-intermediate group for writing skill).

\begin{tabular}{lcccc}
\hline Step & Variables & Sig & Decision & Test result \\
\hline \multirow{2}{*}{ Pretest } & Control & 0.12 & $p>0.05$ & Normal \\
& Experiment & 0.2 & $p>0.05$ & Normal \\
\multirow{2}{*}{ Posttest } & Control & 0.20 & $p>0.05$ & Normal \\
& Experiment & 0.16 & $p>0.05$ & Normal \\
\hline
\end{tabular}

skill variable in the experimental group in the two stages of pretest and posttest are shown in Table 17.

As can be seen in Table 17, there is no significant difference between the mean of the writing skill variable in the pretest and posttest stages in the control group $(\operatorname{sig}=0.36)$ but in the control group and there is a significant difference between the mean of the writing skill variable in the pretest and posttest $(\operatorname{sig}=0.00)$.

Therefore, it can be concluded that, in the experimental group, the average of the writing skill variable in the posttest has significantly increased comparatively to the pretest.

We conducted a test of the second research question in advanced groups, "Does portfolio assessment have a positive effect on Iranian learners' writing skills?”.

Descriptive indices of writing variable scores in the pretest and posttest in advanced-level control and experimental groups that are recorded in Table 18.

As can be seen in Table 18, the average writing skill variable in the advanced control group in the pretest stage is 17.68 and in the posttest stage is 17.60 . Also, the average variable of writing skill in the experimental advanced group in the pretest stage is 17.70 and in the posttest stage is 21.20. It should be noted that the increase in the mean of the writing skill variable in the posttest stage was higher than that in the pretest in the advanced experimental group compared to the advanced control group.

To test this hypothesis, the independent- and pairedsample $t$-test were used. To use these tests, it is necessary to conduct the Kolmogorov-Smirnov test for checking the normality distribution of the whole data in both the pretest and posttest of autonomy and writing tests. Therefore, researchers first examined the assumption of using both the pretest and posttest.
3.8. Score Normality. In this study, the Kolmogorov-Smirnov test was used to investigate the hypothesis of normality of independent variable scores.

The results of the abovementioned test are as given in Table 19.

According to the sig values obtained in Table 19, which are higher than 0.05 , the null hypothesis, i.e., the hypothesis of normality of the discussed variables, is accepted at a significance level of 0.05 .

The results of the independent-sample test for comparing the average of the writing skill variable in the pretest stage between the control and the experimental groups and also in the posttest stage between the control and the experimental groups are given in Tables 20 and 21 .

As can be seen, in the pretest stage, the average of the writing skill variable in the control group was 17.68 and in the experimental group was 17.70 . The results of the independent-sample test at $5 \%$ error level showed $(\operatorname{sig}=0.959)$ that there is no significant difference between the mean of the writing skill variable in the control and the experimental groups in the pretest stage.

Also, in the posttest stage, the average of the writing skill variable was 17.60 in the control group and 21.20 in the experimental group. The results of the independent-sample test was at $5 \%$ error level showed $(\operatorname{sig}=0.00)$ that there is a significant difference between the mean of the writing skill variable in the control and the experimental groups in the posttest stage.

The results of paired-sample test for comparing the average of the writing skill variable in the control group in the two stages of pretest and posttest and also comparing the average of the writing skill variable in the experimental group in the two stages of pretest and posttest are shown in Table 22. 
TABLE 15: Group statistics.

\begin{tabular}{|c|c|c|c|c|c|}
\hline & Group & $\mathrm{N}$ & Mean & Std. deviation & Std. error mean \\
\hline \multirow{2}{*}{ WritingSkill.pre.In } & Control & 30 & 14.28 & 2.57 & 0.47 \\
\hline & Experiment & 30 & 14.61 & 2.24 & 0.40 \\
\hline \multirow{3}{*}{ WritingSkill.pos.In } & Control & 30 & 14.55 & 2.42 & 0.44 \\
\hline & Experiment & 30 & 18.78 & 1.86 & 0.34 \\
\hline & & \multicolumn{4}{|c|}{$t$-test for equality of means } \\
\hline
\end{tabular}

TABLE 16: Independent-sample test.

\begin{tabular}{lcccc}
\hline & $\mathrm{t}$ & $\mathrm{df}$ & Sig. (2-tailed) & Mean difference \\
\hline Writing skill pretest & -0.53 & 58 & 0.59 & -0.33 \\
Writing skill posttest & -7.57 & 58 & 0.00 & -4.23 \\
\hline
\end{tabular}

Table 17: Paired differences.

\begin{tabular}{lllcccrc}
\hline Group & & & Mean & Std. deviation & $\mathrm{t}$ & $\mathrm{df}$ & Sig. (2-tailed) \\
\hline Control & Pair 1 & Writing skill pretest writing skill posttest & -0.266 & 1.57 & -0.92 & 29 \\
Experiment & Pair 1 & Writing skill pretest writing skill posttest & -4.166 & 1.28 & -17.80 & 29 & 0.36 \\
\hline
\end{tabular}

TABLE 18: Descriptive statistic for writing skill in advanced groups.

\begin{tabular}{lllllll}
\hline Advanced group & & $\mathrm{N}$ & Min & Max & Mean & Std. deviation \\
\hline \multirow{2}{*}{ Control } & Autonomy pretest & 30 & 15.00 & 20.00 & 17.68 & 1.38 \\
& Autonomy posttest & 30 & 15.50 & 20.50 & 17.60 & 1.44 \\
\hline \multirow{2}{*}{ Experiment } & Autonomy pretest & 30 & 16.00 & 20.00 & 17.70 & 212 \\
& Autonomy posttest & 30 & 17.00 & 23.00 & 1.13 & 1.39 \\
\hline
\end{tabular}

TABLE 19: Test table for normality of variables in the pretest and posttest (the advanced group for writing).

\begin{tabular}{lcccc}
\hline Step & Variables & Sig & Decision & Test result \\
\hline \multirow{2}{*}{ Pretest } & Control & 0.20 & $p>0.05$ & Normal \\
& Experiment & 0.07 & $p>0.05$ & Normal \\
\hline \multirow{2}{*}{ Posttest } & Control & 0.18 & $p>0.05$ & Normal \\
& Experiment & 0.08 & $p>0.05$ & Normal \\
\hline
\end{tabular}

TABle 20: Group statistics.

\begin{tabular}{lccccc}
\hline & Group & $\mathrm{N}$ & Mean & Std. deviation & Std. error mean \\
\hline \multirow{2}{*}{ Writing Skill.pre.Ad } & Control & 30 & 17.68 & 1.38 & .25 \\
& Experiment & 30 & 17.70 & 1.13 & .207 \\
\hline \multirow{2}{*}{ Writing Skill.pos.Ad } & Control & 30 & 17.60 & 1.44 & .26 \\
& Experiment & 30 & 21.20 & 1.39 & .25 \\
\hline
\end{tabular}

TABLE 21: Independent-sample test.

\begin{tabular}{lcccc}
\hline & \multicolumn{4}{c}{$t$-test for equality of means } \\
& $\mathrm{t}$ & $\mathrm{df}$ & Sig. (2-tailed) & Mean difference \\
\hline Writing skill pretest & -0.05 & 58 & 0.959 & -0.016 \\
Writing skill posttest & -9.83 & 58 & 0.000 & -3.60 \\
\hline
\end{tabular}

TABLE 22: Paired-sample test.

\begin{tabular}{lllccccc}
\hline \multirow{2}{*}{ Group } & & & \multicolumn{2}{c}{ Paired differences } & & \\
& & & Mean & Std. deviation & t & df & Sig. (2-tailed) \\
\hline Control & Pair 1 & Writing skill pretest and writing skill posttest & 0.083 & 2.109 & 0.216 & 29 & 0.830 \\
Experiment & Pair 1 & Writing skill pretest and writing skill posttest & -3.50 & 1.920 & -9.980 & 29 & 0.000 \\
\hline
\end{tabular}


As can be seen from Table 22, in the control group, there is no significant difference between the mean of the writing skill variable in the pretest and posttest (Sig $=0.83$ ), but in the control group, there is a significant difference between the mean of the writing skill variable in the pretest and posttest $(\operatorname{sig}=0.00)$.

Therefore, it can be concluded that, in the experimental group, the average of the writing skill variable in the posttest has significantly increased relatively to the pretest.

\section{Discussion}

This study tried to examine the effect of portfolio assessment on the Iranian EFL learners' autonomy and writing skills in upper-intermediate and advanced levels. Considering the fact that few research has been conducted to compare the impact of alternative assessment techniques, especially portfolio assessment on the autonomy and writing skills in Iran as an EFL context, the researchers felt the need for further research.

4.1. Results of the First Research Question. The result of quantitative data analysis showed that portfolio assessment affected the learners' overall writing. The outcomes supported the findings in [52] and of Belanoff and [53], as cited in $[7,8,50,54-60]$.

Writing is basically a complex process covering selecting, combining, and arranging ideas into a good product. Dealing with the complicated process, according to Lundstrom and Baker [61], writing itself has some aspects which have been categorized into two issues, namely, global issues which consisted of content and organization and local issues, such as vocabulary, grammar, and mechanics. Relating to that statement, it was found that, during the treatment, most learners were confused and faced difficulties when writing a recount text with correct grammar.

Due to this problem, it might be caused by some factors, such as the lack of vocabulary knowledge, the unfamiliarity with the activities, different writing styles, and so on. This condition is basically similar to the study of Eridafithri [62] and Karani [63] where most EFL learners got problems in writing because of grammar and vocabulary. Thus, to overcome the problems encountered by learners when making ineffective writing, teachers can give some feedback on their worksheet by applying portfolio assessment in order to correct their mistakes and enhance their writing ability.

Additionally, a study conducted by Prastikawati, Sophia, and Sodiq [64] find that the mean scores for the five writing aspects of the experimental group got a significant improvement after the treatment. In line with the work of Obeiah and Bataineh [65]; Shokraie and Tabrizi [66]; and Tabatabaei and Assefi [59], learners of the experimental group showed a great improvement in writing ability in terms of content, organization, vocabulary, grammar, and mechanics.

Related to the previous finding, the result of this study showed that using portfolio assessment improved learners' overall writing ability in terms of five important aspects in writing, such as content, organization, vocabulary, grammar, and mechanics. However, the study of Roohani and Taheri [67] shows that portfolio assessment does not affect students' writing ability in terms of vocabulary and mechanics. Also, Uçar and Yazıcı [68] found that there is no significant improvement in portfolio assessment on students' writing ability in terms of mechanics. The improvement score of content in the posttest was in line with the study of Obeiah and Bataineh [65]; Marinho et al. [10]; Prastikawati et al. [64]; and Shokraie and Tabrizi [66], which indicates that the greatest effect of portfolio assessment is on the aspect of the content. Meanwhile, the least improvement of those aspects in this study is grammar and mechanics.

These research findings indicate that writing should not be seen as an activity to produce a product by neglecting the process to reach the goals. Rather, it should be seen as a recursive process in composing a piece of written text for a certain objective, reader, and language use [65]. Furthermore, the use of portfolio assessment in this essay writing class can be considered as a good strategy to make students become more independent learners and self-confident since they become more aware of their own strengths and weaknesses [40].

4.2. The Second Research Question. The research result shows that the students' autonomous learning was improved after the implementation of portfolio assessment. In this regard, portfolio assessment had a positive impact on the learners' autonomy because the portfolio assessment has the sound application of appropriate tasks which creates a balance between "teaching, learning, and testing" [25] and, on the other hand, boosts the learners' awareness of the process of learning.

According to the researchers' study, research findings are in line with the work of Atai and Nikuinezhad [69]. Learners were satisfied with the portfolio method, and at the end of the study, they had a better understanding of their strengths and weaknesses. Also, the finding are in line with Mahdavinia and Ahmadi's study [70], which had shown that using portfolio assessment in class helped students experience self-directed learning, improve their self-confidence, develop self-assessment skills, have a stress-free class, experience a friendly relationship between the teacher and the students, develop their reading, writing, listening, and speaking, and enhance their interest and desire in learning English.

Regarding other studies, again, the finding is in line with the work of Yang [71] and Muin et al. [9] which reported that participants had positive reactions toward using portfolios as a tool for learning and assessment. Students described experiencing a portfolio in their learning as successful. Moreover, portfolios helped enhance participants' learning awareness, facilitate their learning process, and boost their learning autonomy.

Moreover, in line with the work of Lo [72]; Kalyaniwala and Ciekanski [46]; and Shih [21], the finding shows that the participants had neither experience of compiling a portfolio nor knowledge of autonomy. The participants' major tasks 
were to manage their time and learning and develop their skills. It is concluded that the portfolio enabled participants to involve in a learning context and practice autonomous learning. Moreover, the participants' learning awareness was enhanced.

\section{Conclusions}

A portfolio plays a vital role in improving students' writing skills. It is an effective instructional technique as well as an assessment tool that can provide evidence of knowledge and skills. In the EFL context where learning, teaching, and assessment are interrelated, the portfolio can be used as an appropriate mechanism. It can be used to improve the development of EFL learners' writing ability and has a positive effect on their autonomy. In fact, assessment should be considered as a collaborative formative process that helps learners establish a goal to develop their abilities. Learners took the responsibility for their own learning. At the same time, they learned how to be independent and autonomous which is the aim of the learning and assessment.

As a summary of the result of this study, using portfolio assessment techniques can provide useful information about the process of learning. In addition to teacher feedback, learners' engagement and involvement by self-assessing in the process of assessment are considered possible ways of practicing their independence and can remove the gap between what has been taught and what has been learned. In portfolio assessment, researchers have a process of assessing, diagnosing, and the feedback that engages learners; hence, they become more autonomous, responsible, and creative. The result reemphasized the effect of portfolio assessment on Iranian EFL learners' writing ability and autonomy. It should be mentioned that, in portfolio assessment by providing feedback to the learners and engaging them in the process of learning, they can motivate them to improve their general writing ability as well as other writing subskills such as elaboration, organization, content, and vocabulary. Moreover, by studying learners' writing, it was revealed that learners could differentiate descriptive writing from other types of writing, and during the course, they gradually became familiar with the principles of descriptive writing and tried to use them in their writing.

Although the autonomy of the learners was under the focus of this study, the researchers observed that, after receiving the comments and feedback from their teacher, learners paid more attention to their own written texts and tried to find out if they had any clear mistakes. Learners in the experimental group also showed more interest in writing descriptive paragraphs in comparison to the learners in the control group. One reason for this behavior could possibly be linked to the support (feedback and comment) they received from their teacher. On the whole, the atmosphere in the experimental class seemed to be more positive considering their collaboration, working together, and seeking help from each other.

In conclusion, based on the results achieved from the research questions, portfolio assessment has a positive effect on Iranian EFL learner autonomy and writing skill on both upper-intermediate and advanced levels significantly, but this method was more effective for advanced groups. The implication is that portfolio assessment can improve writing ability and can be considered as a motivating strategy. The results of the quantitative analysis revealed that portfolio assessment enhanced learner autonomy and writing skills in the experimental group significantly and offered them the opportunity to reflect upon their learning process, growth, and progress.

Due to some limitations of this study, such as the number of students involved, perhaps further studies should be conducted by adding the number of students as well as a moderate variable such as students' different learning styles in order to obtain more thorough insights related to the power of portfolios in writing classes.

\section{Data Availability}

The datasets used and/or analyzed during the current study are available from the corresponding author on reasonable request. Please contact the author for data requests at cyrosizadpanah@yahoo.com.

\section{Conflicts of Interest}

The authors declare that they have no conflicts of interest.

\section{References}

[1] W. Nur Gita Dahviyanti and I. Iskandar, "Using portfolio assessment to improve EFL students' expository-writing performance," International Journal of Humanities and Innovation (IJHI), vol. 2, no. 1, pp. 1-12, 2019.

[2] T. Sulistyo, K. P. N. Eltris, S. Mafulah, S. Budianto, S. Saiful, and D. F. Heriyawati, "Portfolio assessment: learning outcomes and students' attitudes," Studies in English Language and Education, vol. 7, no. 1, pp. 100-111, 2020.

[3] A. Jaelani and O. W. Zabidi, "Junior high school students' difficulties of English language learning in the speaking and listening section," ELT Forum: Journal of English Language Teaching, vol. 9, no. 1, pp. 45-54, 2020.

[4] J. Barnes, J. Colquhoun, M. Devlin et al., "Designing a portfolio-oriented curriculum using problem based learning," in Proceedings of the 4th Conference on Computing Education Practice 2020, pp. 1-4, Durham United Kingdom, January 2020.

[5] F. Aghajani and H. Salehi, "Effects of montessori teaching method on writing ability of Iranian male and female EFL learners," Journal of Practical Studies in Education, vol. 2, no. 1, pp. 8-15, 2021.

[6] M. Rahimi Rad, "Iranian EFL Learners' use of metadiscourse markers in argumentative writing," Budapest International Research and Critics in Linguistics and Education (BirLE) Journal, vol. 3, no. 3, pp. 1353-1362, 2020.

[7] H. Cho, "Exploring electronic portfolio assessment with secondary emergent $\mathrm{Bi} /$ multilingual students," in CALL Theory Applications for Online TESOL Education, pp. 183202, IGI Global, PA, USA, 2021.

[8] Z. Syzdykova, K. Koblandin, N. Mikhaylova, and O. Akinina, "Assessment of E-portfolio in higher education," International Journal of Emerging Technologies in Learning (iJET), vol. 16, no. 2, pp. 120-134, 2021. 
[9] C. F. Muin, H. Hafidah, and A. M. Daraini, "Students' perceptions on the use of E-portfolio for learning assessment," AL-ISHLAH: Jurnal Pendidikan, vol. 13, no. 1, pp. 497-503, 2021.

[10] P. Marinho, P. Fernandes, and F. Pimentel, "The digital portfolio as an assessment strategy for learning in higher education," Distance Education, vol. 42, no. 2, pp. 253-267, 2021.

[11] N. A. Aini, M. K. Mufid, and E. M. P. Eny Maulita Purnama Sari, "An analysis on IL fossilization phenomenon in students writing performance," Eduvelop, vol. 3, no. 2, pp. 114-130, 2020.

[12] N. Lavoie, M.-F. Morin, M. Coallier, and D. Alamargot, "An explicit multicomponent alphabet writing instruction program in grade 1 to improve writing skills," European Journal of Psychology of Education, vol. 35, no. 2, pp. 333-355, 2020.

[13] D. Nunan, "Closing the gap between learning and instruction," Tesol Quarterly, vol. 29, no. 1, pp. 133-158, 2003.

[14] R. White and V. Arndt, Process Writing, Addison Wesley Longman Ltd, Essex, England, 1991.

[15] B. Ahmadianzadeh, Z. Seifoori, and N. Hadidi Tamjid, "Exploring EFL teachers' beliefs about and practices of learner autonomy across experience and licensure," Innovation in Language Learning and Teaching, vol. 14, no. 2, pp. 97-113, 2020.

[16] H. Reinders, "Towards classroom pedagogy of learner Australian autonomy: a framework of independent language learning skills," Journal of Teacher Education, vol. 35, no. 5, pp. 45-69, 2010.

[17] S. Borg and Y. Alshumaimeri, "Language learner autonomy in a tertiary context: teachers' beliefs and practices," Language Teaching Research, vol. 23, no. 1, pp. 9-38, 2019.

[18] A. I. Challob, "The Effect of Flipped Learning on EFL Students' Writing Performance, Autonomy, and Motivation," Education and Information Technologies, vol. 26, no. 9, pp. 1-27, 2021.

[19] M. A. Desta, "An investigation into the association between learning autonomy, language anxiety and thinking style: university students in focus," Journal of Language Teaching and Research, vol. 11, no. 2, pp. 309-317, 2020.

[20] B. Shen, B. Bai, and W. Xue, "The effects of peer assessment on learner autonomy: an empirical study in a Chinese college English writing class," Studies In Educational Evaluation, vol. 64, pp. 100-109, 2020.

[21] H.-c. Judy Shih, "The use of individual and collaborative learning logs and their impact on the development of learner autonomy in the EFL classroom in Taiwan," Innovation in Language Learning and Teaching, vol. 15, no. 3, pp. 195-209, 2021.

[22] C. Winch, "Autonomy as an educational aim," in The RoutledgeFalmer Reader in Philosophy of Education, pp. 65-73, Taylor and Francis, Oxfordshire, UK, 1st edition, 2021.

[23] M. Hamidnia, S. Ketabi, and Z. Amirian, "Feeding written corrective feedback forward: English language learners' writing improvement in a portfolio-keeping atmosphere," Teaching English Language, vol. 14, no. 1, pp. 31-70, 2020.

[24] R. Lam, "Writing portfolio assessment in practice: individual, institutional, and systemic issues," Pedagogies: International Journal, vol. 15, no. 3, pp. 169-182, 2019.

[25] J. O'Malley and L. Valdez Pierce, Authentic Assessment for English Language Learners: Practical Approaches for Teachers, eddison- Wesley Publishing Company, New York, NY, USA, 1st Ed. edition, 1996.
[26] I. Yurdabakan, "The investigation of peer assessment in primary school cooperative learning groups with respect to gender," Education 3-13, vol. 39, no. 2, pp. 153-169, 2011.

[27] J. A. Virgin and D. A. L. Bharati, "Teachers' perception, plan, and implementation of portfolio assessment in students' writing assessment," English Education Journal, vol. 10, no. 2, pp. 143-153, 2020.

[28] A. Syamsul Ma'arif, F. Abdullah, A. Siti Fatimah, and A. Nurul Hidayati, "Portfolio-based assessment in English language learning: highlighting the students' perceptions," J-SHMIC: Journal of English for Academic, vol. 8, no. 1, pp. 1-11, 2021.

[29] D. Brown, Language Assessment: Principles and Classroom Practice, Pearson Education, White Plains, NY, USA, 2004.

[30] K. Hyland, Second Language Writing, Cambridge University Press, London, England, 2003.

[31] A. Nazari Terizi and D. Mohammadi, "The effect of applying portfolio in improving Arabic learning for eleventh grade high school students in isfahan," The Journal of Research in Humanities, vol. 28, no. 2, pp. 171-191, 2021.

[32] S. L. Sri Lestari Siregar, M. O. F. Gafari, and M. Malan Lubis, "The development of portfolio based short text writing assessment instrument in 11th grade of senior high school (SMAN 1) panai tengah," Britain International of Linguistics Arts and Education (BIoLAE) Journal, vol. 2, no. 2, pp. 622634, 2020.

[33] U. Soifah and B. W. Pratolo, "Teachers' belief, implementation, and challenges in portfolio assessment in writing," Journal of Critical Reviews, vol. 7, no. 9, pp. 986-990, 2020.

[34] F. Ebrahimi, E. Namaziandost, M. Ziafar, and P. M. Ibna Seraj, "The effect of teaching formulaic expressions through contrastive lexical approach on Iranian pre-intermediate EFL learners' writing skill," Journal of Psycholinguistic Research, vol. 50, no. 5, pp. 1087-1105, 2021.

[35] R. Ş. Arsalan and S. N. Gümüş, "The effect of portfoliokeeping on EFL young learners' writing achievement and their motivation towards writing," Journal of Narrative and Language Studies, vol. 8, no. 14, pp. 130-150, 2020.

[36] A. Yundayani and L. S. Ardiasih, "Task-based material design for academic purposes: learners' English writing skill improvement," Studies in English Language and Education, vol. 8, no. 1, pp. 258-275, 2021.

[37] H. Haerazi, L. A. Irawan, T. Suadiyatno, and H. Hidyatullah, “Triggering preservice teachers' writing skills through genrebased instructional model viewed from creativity," International Journal of Evaluation and Research in Education, vol. 9, no. 1, pp. 234-244, 2020.

[38] T. Hedge, Writing, Oxford University Press, Oxford, UK, 2005.

[39] W. Wang, W. Li, N. Zhang, and K. Liu, "Portfolio formation with preselection using deep learning from long-term financial data," Expert Systems with Applications, vol. 143, Article ID 113042, 2020.

[40] H. Haerazi, I. M. P. Utama, and H. Hidayatullah, "Mobile applications to improve English writing skills viewed from critical thinking ability for pre-service teachers," International Journal of Interactive Mobile Technologies (iJIM), vol. 14, no. 07, pp. 58-72, 2020.

[41] L. Yan, "Final paper as portfolio: an academic writing assessment for incipient college student writers from large classes," Asian Research on English for Specific Purposes, Springer, Singapore, pp. 251-267, 2020.

[42] A. A. F. Alzubi, "The role of mobile technologies in impacting learner autonomy in an EFL context," International Journal of 
Computer-Assisted Language Learning and Teaching, vol. 11, no. 3, pp. 56-73, 2021.

[43] L. Li and S. Kim, "To enhance non-English major students' English communicative competence by improving students' English learner autonomy through organization development interventions-an action research at zhejiang yuexiu university of foreign languages (ZYUFL) in China," $A B A C$ ODI journal vision. action. outcome.vol. 7, no. 1, pp. 22-47, 2020.

[44] F. Vieira, "Pedagogy of experience in teacher education for learner and teacher autonomy," Profile - Issues in Teachers' Professional Development, vol. 22, no. 1, pp. 143-158, 2020.

[45] W. He, "Autonomous development strategies for college English teachers in a mixed-mode learning community," Journal of Contemporary Educational Research, vol. 4, no. 3, 2020.

[46] C. Kalyaniwala and M. Ciekanski, "Autonomy CALLing: a systematic review of 22 years of publications in learner autonomy and CALL," Language, Learning and Technology, vol. 25, no. 2, 2021.

[47] D. Little, Learner Autonomy, Teachers Autonomy and the European Language Portfolio, UNTELE, University of Compiègne, Compiègne, France, 2004, http://www.utc.fr/\% 7Euntele/2004ppt/handouts/little.pdf.

[48] P. A. Tyas, "Promoting students' autonomous learning using portfolio assessment in EFL writing class," JEE, vol. 5, no. 1, pp. 75-81, 2020.

[49] M. Fahim and R. S. Behdani, "Critical thinking ability and autonomy of Iranian EFL learners," American Journal of Scientific Research, vol. 29, pp. 59-72, 2011.

[50] Y. H. Wang and H. C. Liao, "The application of learning Portfolio assessment for students in the technological and vocational education system," Asian EFL Journal, vol. 10, no. 2, pp. 132-154, 2008.

[51] R. T. Lange, Inter-rater Reliability: Encyclopedia of Clinical Neuropsychology, Springer, New York, NY, USA, 2011.

[52] W. F. Al-Serhani, The Effect of Portfolio Assessment on the Writing Performance of EFL Secondary School Learners in Saudi Arabia. Kingdom of Saudi Arabia, Taibah University, Taibah, Saudi Arabia, 2007.

[53] P. Belanoff and M. Dickson, Portfolios: Process and product, JSTOR: Boyton/Cook, New York, NY, USA, 1991.

[54] A. Sharifi and J. Hassaskhah, "The role of portfolio assessment and reflection on process writing," Asian EFL Journal, vol. 13, no. 1, pp. 193-223, 2011, http://www.asian-efl-journal.com/ PDF/March-2011.pdf.

[55] N. Barootchi and M. H. Keshavarz, "Assessment of achievement through portfolios and teacher-made tests," Educational Research, vol. 44, no. 3, pp. 279-288, 2002.

[56] M. Caner, "Students' view on using portfolio assessment in EFL writing course," Cilt, vol. 10, no. 1, pp. 223-236, 2010.

[57] B. Ghoorchaei, M. Tavakoli, and D. Ansari, "The impact of portfolio assessment on Iranian EFL learners' essay writing: a process-oriented approach," GEMA Online тм Journal of Language Studies, vol. 10, no. 3, pp. 121-138, 2010.

[58] L. Qinghua, "The impact of portfolio-based writing assessment on EFL writing development of Chinese learners," Chinese Journal of Applied Linguistics, vol. 33, no. 2, pp. 103-116, 2010.

[59] O. Tabatabaei and F. Assefi, "The effect of portfolio assessment technique on writing performance of EFL learners," English Language Teaching, vol. 5, no. 5, pp. 138-147, 2012.

[60] I. Yurdabakan and T. Erdogan, "The effect of portfolio assessment on reading, listening, and writing skills of secondary school class students," The Journal of International Social Research, vol. 2, no. 9, pp. 526-538, 2009.

[61] K. Lundstrom and W. Baker, "To give is better than to receive: the benefits of peer review to the reviewer's own writing," Journal of Second Language Writing, vol. 18, no. 1, pp. 30-43, 2009.

[62] E. Eridafithri, "The application of portfolios to assess progress in writing of EFL students at secondary schools in Banda Aceh," Studies in English Language and Education, vol. 2, no. 1, pp. 1-15, 2015.

[63] E. Karani, "Area of problems in writing recount text," Jurnal Pendidikan Inovatif, vol. 4, no. 1, pp. 10-13, 2008.

[64] E. F. Prastikawati, T. C. Sophia, and J. Sodiq, "Portfolio assessment's impact on writing ability of English Foreign Language (EFL) learners," Journal of Research \& Method in Education, vol. 6, no. 6, pp. 11-18, 2016.

[65] S. F. Obeiah and R. F. Bataineh, "The effect of portfolio-based assessment on Jordanian EFL learners' writing performance," Bellaterra Journal of Teaching \& Learning Language \& Literature, vol. 9, no. 1, pp. 32-46, 2016.

[66] S. Shokraie and A. Tabrizi, "The effect of portfolio assessment on EFL learners' L2 writing performance," Journal of Applied Linguistics and Language Research, vol. 3, no. 5, pp. 321-331, 2016.

[67] A. Roohani and F. Taheri, "The effect of portfolio assessment on EFL learners' expository writing ability," Iranian Journal of Language Testing, vol. 5, no. 1, pp. 46-59, 2015.

[68] S. Uçar and Y. Yazıcı, "The impact of portfolios on enhancing writing skills in ESP classes," Procedia - Social and Behavioural Sciences, vol. 232, pp. 226-323, 2016.

[69] M. Atai and F. Nikuinezhad, "The effect of portfolio assessment on metacognitive reading strategy awareness of Iranian EFL students," Asian EFL Journal, vol. 9, no. 2, 2006.

[70] M. Mahdavinia and L. N. Ahmadi, "Portfolio assessment: a tool for self-directed learning at post-secondary level," in Fostering Autonomy in Language Learning, D. Gardner, Ed., pp. 76-89, Zirve University, Gaziantep, Turkey, 2011, http:// ilac2010.zirve.edu.tr.

[71] N. D. Yang, "Integrating portfolios into learning strategybased instruction for EFL college learners," International Review of Applied Linguistics in Language Teaching, vol. 41, no. 4, pp. 293-317, 2003.

[72] Y.-F. Lo, "Implementing reflective portfolios for promoting autonomous learning among EFL college students in Taiwan," Language Teaching Research, vol. 14, no. 1, pp. 77-95, 2010. 